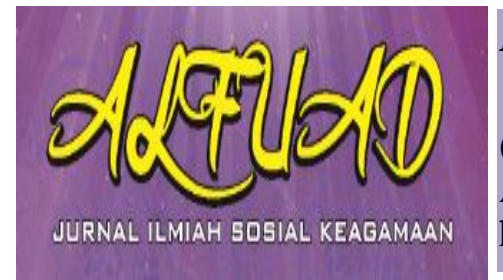

ALFUAD JOURNAL, 5 (2), 2021, (26-37)

(E-ISSN 2714-7606 P-ISSN 2614-4786 )

Available online at

http://ecampus.iainbatusangkar.ac.id/ojs/index.php/alfuad

\title{
Social Values in Funerary Ceremony Research on Lintau Buo Community, Tanah Datar Regency
}

\author{
Siska Elasta Putri \\ Institut Agama Islam Negeri Batusangkar, \\ Indonesia \\ E-mail: \\ siskaelastaputri@iainbatusangkar.ac.id
}

\begin{abstract}
This research aimed at studying social values in conducting a funerary ceremony which was held by Lintau Buo community. This funerary ceremony is a customary rite that must be held by the community. It is due to the status of this ceremony as the main customs (adat nan teradat). A qualitative method with an ethnography approach was used in conducting this research. The result showed that the social values in the funerary ceremony were mutual help, solidarity, kinship, reciprocity, communication, harmony, and concern.
\end{abstract}

Keywords: Social Values, Funerary Ceremony

\section{INTRODUCTION}

Social values are the values embraced by a community. It can also be defined as the faith and viewpoint of the members of a community (Putri et al., 2019). These values contain something about good or bad, things that are appropriate or inappropriate to do, worthy or not worthy to carry out (Sasmita, 2018). These social values are functioned to lead and regulate the community to think and act (Basyari, 2011). They can also be functioned to give motivation to somebody to determine his/her role and position in the community. Furthermore, it has a purpose as directions and unifier, protection, and booster (Aisah, 2015). Another function of social values is as a medium to create social solidarity in a group of people.

The form of social value is a social norm. It is because values and norms are unity and they relate to each other. Value as something abstract turns into reality when it comes to human actions (Parmono, 1995). Values are the guideline in setting the norms, and then the norms become the guidance for behavior (Rochmadi, 2012). Someone's behavior which reflects the values is used as a guide. This guidance is called norms. If someone acts based on the values and norms, then he/she indirectly create values through norms.

In Minangkabau community, social values are created in customary law. Minangkabau's customary law is divided into 4 types: adat nan sabana adat (custom based on religious law), adat nan 
diadatkan (custom based on agreement), adat nan teradat (custom based on standard rule), and adat istiadat (custom based on specific local culture which can vary from one territory to another) (Gani, 2012). Adat nan sabana adat is the main rule or philosophy which underlies the lives of Minangkabaunese community and is not affected by place, time, and state. Adat nan sabana adat is the provisions of God and prophet Muhammad which become eternal and immutable natural law (Jonaidi, 2018). Adat nan diadatkan is the customs composed by Minangkabaunese's ancestors which contain guidance to adapt to the state and the nature or environment (Anwar, 1997). Meanwhile, adat nan teradat is the rules set based on the agreement of local male authorities and the traditional male leaders in every territory in Minangkabau (Anwar, 1997). The last is adat istiadat, this custom is the regulation that considers youth's desire, joy, entertainment, interest, and talent (Anwar, 1997). Those customs are used as a foundation and philosophy in life and become the culture of Minangkabau community. Custom contains social rules that organize a community's life pattern which is arranged based on agreement and passed down from generation to generation.

One of adat nan teradat customs that is embraced by Lintau Buo community is concerning the funerary ceremony. The rite consists of manigo hari(the third day), manujuah hari (the seventh day), duo kali tujuah haril 2x7 (the fourteenth day), tigo puluah hari(the thirtieth day), ampek puluah hari(the fortieth day), limo puluah hari(the fiftieth day), anam puluah hari(the sixtieth day), tujuah puluah hari(the seventieth day), salapan puluah hari(the eightieth day), sambilan puluah hari (the ninetieth day), manyaratuih hari (the one-hundredth day), and saratuih sapuluah hari (the one hundred tenth day).

Based on the obligation to hold the ceremony, the funerary ceremony is obligatory. It is due to the status of this ceremony as adat nan teradat in Lintau Buo community (Putri, 2020). The execution of a funerary ceremony is held regardless of the status, position, and social class of an individual. Able or unable, rich or poor, oligarch or ordinary person, all have to hold funerary ceremonies when their family members pass away. There is no written penalty if there is a family that does not hold the ceremony, but there will be social punishment such as public shaming and criticism.

It is interesting to study deeper the process of holding the funerary ceremony. The process which has been the culture in community contains social values and local wisdom by which it still exists today. 
Hence, this study is the discussion of social values contained in a funerary ceremony in Lintau Buo community of Tanah Datar regency.

\section{METHOD}

A qualitative method was used in conducting this research. Deeper information from the informants was expected by using this method. Based on the type, this article is categorized as an ethnography study which is one of the research methods to describe culture based on research's observation. The technique and procedure were observation and deep interview by using emic perspective by which community's perspective was studied. By using ethnography study, it was expected that social values of funerary ceremony could be described well based on the perspective of Lintau Buo community.

\section{RESULT AND DISCUSSION}

\section{Funerary Ceremony}

Funerary ceremony is one of the traditional ceremonies that is strongly required to hold. The obligation to conduct this ceremony results from the status of this ceremony as adat nan teradat \{Molehardi Dt. Abu Bakar (45 years old), December 2020\}. Custom is the rule of life, even though it is not written by the government but it is respected and obeyed by society with the faith that these rules are stated as law (C. Dewi Wulansari, 2016). It means, as one of the customs, society is strongly required to hold it. The reason is that custom is the rule that must be obeyed by society as guidance for behaviors and actions.

If one of the families in the community mourns, then the funeral rite will be held based on Islamic faith: washing the body, covering the body with a sheet, praying, and burial. After finishing the process, there will be a funerary ceremony (Sirman Ampono Alam (49 years old, December 2020) and Zulpahman mantiko Dubalang (51 years old, December 2020) described the rite of the funerary ceremony as follow:

\section{Manigo Hari (The Third Day)}

Manigo hari is a funerary ceremony that is held three days after the funeral. Manigo hari is held after maghrib (after sunset) prayer. The activities in this event are reciting the holy Quran. It is attended by niniak mamak (respected traditional male leaders), tuangku (respected religious leaders), neighbors, and also anak surau \{the youth who study religious instruction and the holy Quran in surau (an Islamic assembly building)\}. This ceremony will be ended by praying together led by tuangku, to ask for patience and strong faith for the mourning family and ask for 
salvation from the punishment of the grave and the hell for the deceased person.

\section{Manujuah Hari (The Seventh Day)}

Manujuah hari is one of the ceremonies held by the mourning family on the seventh day after the death. Manujuah hari is also held after maghrib (after sunset) prayer. This ceremony is also called mananam tuangku. It means when this ceremony is held, niniak mamak will appoint a tuangku who will be in charge of praying every day in the mourning family's house. The appointed tuangku will come to that house on the following days until the one-hundredth day. In manujuah hari ceremony, the mourning family also prepares dinner for the invited community. After having dinner together, this ceremony is ended by praying which is led by tuangku.

\section{$2 x 7$ (Two Times Seven)}

The ceremony that is held on this $2 \times 7$ occasion is manamaik kaji anak surau (accomplishing anak surau's Quran recitation study). Anak surau has come to the mourning family's house since the first night after the deceased person's funeral, thus in this stage, they will accomplish Quran recitation. The community members who mourn will also come to this ceremony. They will come and bring rice that they put in a bowl and wrapped it with a handkerchief. For this ceremony, the mourning family will cook a meal and serve it to the mourners. After that, the anak surau will finish their recitation, then a packed dinner and an envelope filled with money will be given to them by the mourning family. Then, they will have dinner together. After dinner, tuangku will lead them to pray together as the ending of the ceremony.

Tigo Puluah Hari, Ampek Puluah Hari, Limo Puluah Hari, Anam Puluah Hari, Tujuah Puluah Hari (The Thirtieth, The Fortieth, The Fiftieth, The Sixtieth, and The Seventieth Days)

Several ceremonies will be held on the thirtieth, the fortieth, the fiftieth, the sixtieth, and the seventieth days after the funeral. In these ceremonies, the mourning family will also prepare and serve meals. However, the guests who come to these ceremonies are not the invited ones, but only the relatives. These ceremonies are also ended by praying together which is led by tuangku.

\section{Salapan Puluah Hari(The Eightieth Day)}

Salapan puluah hari ceremony is categorized as a quite big ceremony because it is attended by niniak mamak (respected traditional male leaders), bundo kanduang (respected traditional female leaders), tuangku (respected religious leaders), and sepesukuan relatives (relatives from the same tribe). They will 
talk about holding manyaratuih hari ceremonies, whether the ceremony will be dipagadang (big) or dipaketek (small) and who will be invited (dipanggia). They also talk about the tools needed, kapalo $d u$ 'a (the gift for tuangku), and the person who will do maulud, and the exact day of doing mutual help. Mutual help is usually done three days before manyaratuih hari.

"Alek" is the concept used by the community for "party". Alek is dipagadang or dipaketek means that the concept of party will be adjusted based on the economic condition of the mourning family. If they are middle to upper class, manyaratuih hari ceremony will be big, and vice versa, if they are middle to lower class, the event will be small. It can be seen from 3 things: the slaughtered animal, the served meals, and the invited people. For the big occasion, the slaughtered animal will be a cow or a buffalo, meanwhile, for the small occasion, the mourning family will slaughter a goat or buy some kilos of meat (Jusmaini, 57 years old, December 2019).

Dipanggia is a verbal way to inform the community to attend manyaratuih hari. The type of alek will affect the number of invited people. If it is a big alek, then there will be many people invited to the occasion, not only the community members but also the acquaintances or friends of the mourning family. On the other hand, it will be different from the small occasion (small alek), the guests are only the closest people.

The tools needed in holding manyaratuih hari are a tent, bauangbauang or temporary kitchen, kancah or big cooking pan, eating utensils, tables, and chairs, rug, etc. The tent is used as a shade for the guests. Bauang-bauang or a temporary kitchen is used by the women as a kitchen. Kancah or a big cooking pan is used for cooking the meal. Eating utensils such as plates, glasses, spoons, forks, bowls, etc, are also used for serving meals. Rugs, chairs, and tables are for the guests to sit when they have the meals.

Kapalo duá is about giving some equipment to the tuangku such as bed, blanket, pillow, toiletries, shirt, pants, sandals, cap, and eating utensils such as plate, glass, spoons, etc. giving kapalo dua to tuangku is for paying back his sincerity after coming to the mourning family's house for praying since the fourteenth until the one hundred tenth day.

\section{Sambilan Puluah Hari(The Ninetieth Day)}

The ceremony held on the ninetieth day is the same as the ceremonies held on the thirtieth, fortieth, fiftieth, sixtieth, and seventieth days. The differences are only the dates. 
Manyaratuih Hari (The One-Hundredth Day)

Manyaratuih hari is the peak of all the funerary ceremonies. On the day of manyaratuih hari, the mourning family gives meals to the invited community. The guests who have been informed about this day through verbal invitation called dipanggia will come at 02:00 pm until 10:00 pm. All community members such as the respected male leaders, female leaders, brothers-in-law, and other community members will attend the occasion.

Manyaratuih hari is divided into two groups: day event (alek siang) and evening event (alek malam). Women will come to the day event; meanwhile, the evening event is for the men. The women will start coming at 02:00 pm until after maghrib (after sunset) prayer. On the other hand, the men will start coming at 08:00 pm.

The guests will come to the house by bringing something based on their relation to the mourning family. The closest relatives of the deceased person will bring rice in a bowl that is wrapped with a handkerchief, amai or the wife of mamak (uncles) will bring a bigger tray that contains 11 kinds of food, and neighbors from the same tribe will bring rantang which contains rice and eggs, or rice and small cakes. On the other hand, men do not bring anything.
The evening occasion starts at 09:00 pm. This event is attended by respected traditional male leaders, respected religious leaders, brothers-in-law, and other men. When they have already come, the occasion will be started by reciting some verses of the Quran together, after that, the meals will be served by brothersin-law. After serving the meals, they will have dinner together. Then, the brothersin-law will do the clean-up after dinner. The next stage is reciting some short verses of the Quran such as Al-Ikhlas verse. Then they will have desserts (juadah) such as fried banana, white sticky rice, yellow sticky rice, pinyaram, wajik, and cakes that come with cups of coffee as well. After finishing juadah, one of the respected religious leaders (tuangku) will lead the prayer. This occasion is then ended by doing sombah manyombah which contains asking for permission to go back home.

The last stage of manyaratuih hari is maulud. Maulud is telling the life story of Prophet Muhammad which is told in Arabic. Maulud is usually delivered by 6 people. Maulud is held from 10:00 pm until 03:00 am. In the morning, the mourning family will deliver kapalo $d u^{\prime} a$ to the tuangku's house. 
The One Hundred Tenth Day.

This ceremony is held on the one hundred tenth day after the funeral. This ceremony is the last and the end of the series of funerary ceremonies.

\section{Social Values in Funerary Ceremony}

Value is defined as an abstract concept that cannot be seen or touched (Mundzir, 2014). This concept is internalized into the human mind and becomes a system of value. Something will not have meaning without the existence of value. It means the value is extremely significant for the existence of a thing. Hence, in holding a funerary ceremony, some social values keep the ceremony lasting. There are local wisdom values that the community members have which make this culture lasts and is not affected era by era. The values in the funerary ceremony are as the following:

\section{Mutual Help}

Mutual help is an important activity to finish work. Mutual help is defined as someone's participation to give value to others by which it can be in the form of money, energy, skill, idea, etc (Rochmadi, 2012). Mutual help is also defined as agreed teamwork. Mutual help is not only about physical activity, but also about social values.

In conducting a funerary ceremony, mutual help has a significant role. The form of mutual help can be seen in every stage of the process such as helping the mourning family cook and serve the meals, preparing the tools and materials needed, providing the fund, inviting guests, building a temporary kitchen (bauangbauang), etc.

Mutual help is also done based on the value of humans as social beings that cannot live alone. Humans will depend on one another and maintain a good relationship. Koentjaraningrat says that one of the forms of mutual help is in responding to accidents, disasters, and death (Irfan, 2017). Mutual help culture is not something new to human life. Mutual help cannot be separated from both traditional and modern communities. Every person has close relatives, best friends, group of friends, working environment, etc.

\section{Reciprocity}

Reciprocity can be simply interpreted as a reciprocal exchange between individuals and individuals or groups with groups (Sairin, 2002). In that exchange, someone will give and take something or kindness due to social responsibility (Pribadhi, 2011). Reciprocity is based on the basic economic transaction principle which means someone provides something and shares kindness and hopes that he/she will get the same later. Hence, the recipient 
should give back what he/she has ever taken in the same or different way it is. In a funerary ceremony, the mourning family will receive help in the form of material or moral. Materials support can be money, food, or tools. Meanwhile, moral support can be in the form of help for preparing and conducting funerary ceremonies. This help is given by relatives, friends, neighbors, and other community members. This support is given to lighten the burden of the mourning family in holding the ceremony.

Even though it is functioned as lightening the burden, but after the ceremony, the mourning family should give the same support if it also happens later to another family. it also works for other families in the community, they will expect the same help if it happens to them in the future. This kind of reciprocal relationship has been passed down from generation to generation in the community. There is a responsibility in taking and giving those materials and moral support.

\section{Social Solidarity}

The next value is solidarity value. As discussed previously, there is mutual help value that is maintained in the community. This value emerges because of the solidarity value in the community. Solidarity can be simply defined as solid nature and feelings or loyalty of friends
(Mundzir, 2014). Good solidarity that is established in the community will result in the emotional connection among them and will last longer.

Emile Durkheim, a sociologist, divides society based on solidarity bond which is categorized into mechanical and organic types of society (Ritzer, 2010). Mechanical solidarity is based on a shared collective awareness which shows the totality of trusts, beliefs, and shared sentiments that exists in the community. Such solidarity depends on the individuals who have the same traits, faith, normative pattern (Lawang, 1994). On the other hand, organic type or what is so-called modern society or urban dwellers have a relationship that tends to be individual without being based on a strong sense of kinship. This type of community is more rational and they tend to rely on common sense. Their occupations are also specialized and it results in one of differentiating factors between high class and lower class society.

One of the factors that strengthen social solidarity is religion. Emile Durkheim found that the essence of religion has two functions as a source and solidarity builder in society. She states that religion is a regulation needed by society to bind individuals into one unit through the formation of belief systems and rituals in every culture; religion is the most 
valuable part of social life. It serves society by providing ideas, rituals, and feelings that lead someone to live social life (Lawang, 1994). The relationship between religion and society appears in rituals matters. A ritual that gathers people in manyaratuih hari ceremonies emphasizes the mechanical solidarity in the community. Religion has functioned as a community integration tool, and holding manyaratuih hari emphasizes human obedience to religion that strengthens community solidarity.

Durkheim also states that religious rituals are the most important because these rituals lead to belief. There will always be a need for society to hold rituals and ceremonies because these are the sources of social unit and the main binding rope for all members of society (Pals, 2011). Manyaratuih hari ceremony is one of the rituals or ceremonies that strengthens the bond that makes an individual stick to his/her social group. Moreover, holding manyaratuih hari together and comforting the grieving family can reduce the sorrow because they will feel protected by their group.

Religious ritual is the medium to connect a person with his/her relatives. It is not only a medium to strengthen the group's social bond and reduce the suspense, but also become a way to celebrate important events or incidents like death. Thus, the mourning family will be more relieved (Dillistone, 2002). By holding manyaratuih hari, a community can lighten the sorrow of the mourning family, maintain a good relationship by bringing back the faded values, and strengthen social solidarity.

\section{Kinship}

Manyaratuih hari ceremonies cannot be separated from kinship values. When there is a family member passes away, the news will be spread immediately by announcing it in the nearby mosque or mushala, using phones, or telling the relatives and neighbors directly. Just like Minangkabaunese's proverb, kaba baiak bahimbauan, kaba buruak bahambauan. The meaning of this proverb is both good news like a party and bad news like death, accident, or sickness will be informed directly to relatives, neighbors, and other community members.

The community members who hear the bad news will also mourn. They will go immediately to the mourning family's house and some of them even take part in doing the funeral rites. It is continued until the one hundred tenth day. Even in holding funerary ceremony, they also take the parts in preparing and carrying out. The women will help cook and serve the meals; meanwhile, the men will prepare the tools and equipment needed. Thus, kinship 
values are not only felt by the mourning family, but also by the neighbors and surrounding community members (Alwani \& Erianjoni, 2019).

\section{Communication}

Communicative value is one of the most important parts of holding a funerary ceremony. If there is no good communication among the community members, then the process of preparing and carrying it out will not run well. For instance, when there is a community member who is invited to help manyaratuih hari ceremony, he/she will come to help. Yet, if there is no good communication or the person is not informed, then he/she will feel unwilling to help.

Similarly, when the mourning family does not invite certain community members to have meals together in manyaratuih hari ceremonies, they will not come. It is because they do not get social responsibility to come to the ceremony.

\section{Harmony}

Harmony is defined as a harmonious, dynamic, and peaceful relationship as the effort to strengthen the relationship. It results from mutual love in family and society. Harmony in carrying out funerary ceremonies has an important function. This ceremony becomes the booster in building togetherness, giving appreciation, and as a mechanism in avoiding conflict and breaking the unity in society (Haryanto, 2014).

The funerary ceremony also has a function to maintain a social bond in society. Community members carry out internal interaction in the family and external interaction in society that includes community members. This interaction is based on equality in achieving the shared goal which is harmony in the community.

\section{Concern}

Caring is a feeling of sympathy that humans have when they see other humans in trouble. As discussed previously, the funerary ceremony is a ceremony that is carried out when a member of the community passes away. Hence, the community members will come to help. They feel concerned about the fate experienced by the mourning family. By caring about the fate of others, those grieving people will be touched. Thus, they will always remember the support they receive and help back if the helpers experience the same thing someday

\section{CONCLUSION}

A funerary ceremony is a ceremony that must be carried out by Lintau Buo community. This ceremony is strongly required if there is a family member in the 
community passes away. The implementation of this ceremony does not consider someone's social status, class, or position in the community. The lower people must hold this ceremony. It is because of the status of this ceremony as adat nan teradat.

The obligation to carry out this ceremony cannot be separated from social values. These social values become the factors of the existence and continuity of this ceremony. Based on the discussion above, it can be concluded that social values contained in funerary ceremonies are mutual help, solidarity, kinship, reciprocity, communication, harmony, and concern.

\section{REFERENCES}

Aisah, S. (2015). Nilai-Nilai Sosial yang Terkandung dalam Cerita Rakyat "Ence Sulaiman" pada Masyarakat Tomia. Jurnal Humanika, 3(15), 1689-1699.

Alwani, R., \& Erianjoni, E. (2019). NilaiNilai Solidaritas Sosial dalam Komunitas Penari Lintas Community (PLC) Kota Payakumbuh. Culture \& Society: Journal Of Anthropological Research, 1(1), 62-68. https://doi.org/10.24036/culture/vol1iss $1 / 9$

Basyari, H. I. W. (2011). NILAI-NILAI

KEARIFAN LOKAL (LOCAL WISDOM) TRADISI MEMITU PADA MASYARAKAT CIREBON (Studi Masyarakat Desa Setupatok Kecamatan Mundu). Phys. Rev. E.
C. Dewi Wulansari. (2016). Hukum Adat di Indonesia. 175.

Gani, E. (2012). Kajian Terhadap Landasan Filosofi Pantun Minangkabau. Komposisi: Jurnal Pendidikan Bahasa, Sastra, Dan Seni, 10(1), 1-10. https://doi.org/10.24036/komposisi.v $10 \mathrm{i} 1.49$

Haryanto, J. T. (2014). Kearifan Lokal Pendukung Kerukunan Beragama pada Komuntias Tengger Malang Jatim. Analisa, 21(2), 201. https://doi.org/10.18784/analisa.v21i 02.15

Irfan, M. (2017). Metamorfosis Gotong Royong Dalam Pandangan Konstruksi Sosial. Prosiding Penelitian Dan Pengabdian Kepada Masyarakat, $\quad 4(1), \quad 1$. https://doi.org/10.24198/jppm.v4i1.1 4204

Jonaidi. (2018). Kajian Hukum Terhadap Tanah Ulayat Masyarakat Hukum Adat Minangkabau di Sumatera Barat. Lex Et Societatis, VI(1), 97 106.

http://dx.doi.org/10.1016/j.encep.201 2.03.001

Mundzir, C. (2014). Nilai Nilai Sosial Dalam Tradisi Mappanre Temme' Di Kecamatan Tanete Rilau, Kabupaten Barru. Rihlah, I(2), 69-81.

Parmono. (1995). Nilai dan Norma Masyarakat. Jurnal Filsafat, 23.

Pribadhi, P. A. (2011). Resiprositas Dalam Kehidupan Sosial Ekonomi Masyarakat (Studi Kasus Pada Masyarakat Kelurahan Kauman Kabupaten Blora). Skripsi Universitas Negeri Semarang.

Putri, S. E. (2020). Upacara Kematian Pada Masyarakat Nagari Taluak Kecamatan Lintau Buo Kabupaten 
Tanah Datar Dalam Perspektif Hukum Islam. JURIS (Jurnal Ilmiah Syariah), $\quad$ 19(1), 73. https://doi.org/10.31958/juris.v19i1.1 997

Putri, S. E., Damsar, D., \& Alfiandi, B. (2019). PEMETAAN JARINGAN SOSIAL DALAM ORGANISASI: Studi Pada Distributor Tupperware Unit Simabur Indah di Batusangkar. Jurnal Antropologi: Isu-Isu Sosial Budaya, 20(2), 129. https://doi.org/10.25077/jantro.v20.n 2.p129-143.2018

Rochmadi, N. (2012). Menjadikan Nilai Budaya Gotong Royong sebagai Common Identity dalam Kehidupan Bertetengga Negara-Negara ASEAN. Repository Universitas Negeri Malang, 1, 1-9.

Sasmita, W. (2018). Tradisi Upacara Ritual Siraman Sedudo Sebagai Wujud Pelestarian Nilai-Nilai Sosial. Jurnal Ilmiah Pendidikan Pancasila Dan Kewarganegaraan, 3(2), 207. https://doi.org/10.17977/um019v3i2p 207-214

Lawang, Robert M.Z. 1994. Teori Sosiologi Klasik dan Modern. Jakarta: Gramedia Pustaka Utama

Ritzer, George. 2010. Teori Sosiologi.

Bantul: Kreasi Wacana 